\title{
Effects of outreach on the awareness and adoption of conservation practices by farmers in two agricultural watersheds of the Mackinaw River, Illinois
}

\author{
A.M. Lemke, T.T. Lindenbaum, W.L. Perry, M.E. Herbert, T.H. Tear, and J.R. Herkert
}

\begin{abstract}
Increased awareness of the contributions of nonpoint source runoff to the degradation of water quality in the Mississippi River and Gulf of Mexico emphasizes the need to increase conservation practices that reduce nutrient export from agricultural lands. To achieve long-term conservation goals in agricultural landscapes, it is important to understand farmers' perspectives on what practices are effective, practical, and economically attainable. We conducted a series of surveys, interspersed with focused outreach, of farmers in two agricultural watersheds in central Illinois in an attempt to better understand how outreach influenced their views on and adoption of conservation practices. Programs differed between the two watersheds in terms of the levels of intensity at which outreach efforts were conducted. Survey results suggest that more intensive outreach efforts, such as one-on-one landowner visits, localized workshops, and tours, can increase adoption of conservation practices associated with cost-share programs. Technical and financial assistance provided in a timely manner that did not interfere with planting and harvesting were major incentives among farmers in both watersheds to participate in cost-share conservation programs. Primary disincentives among farmers to enroll in cost-share programs were associated with multiple programmatic changes and complex application processes. Results indicate that there remains a need for outreach that increases awareness and implementation of conservation and best management practices specific to reducing agricultural runoff from tile-drained sources. Mitigation of nonpoint runoff will also require more effective management of nitrogen application rates and timing in order to conserve freshwater resources in Midwest agricultural landscapes and downstream waters. Integrated outreach teams comprised of stakeholders and local conservation agencies may lead to successful outreach efforts and reduce demands on limited conservation agency staff time.
\end{abstract}

Key words: agriculture — best management practices—nitrogen—outreach effectiveness — stream

Throughout the Midwest United States, there is increasing pressure to alter agricultural practices in ways that reduce nutrient exports to the Mississippi River and the Gulf of Mexico. Although numerous state, federal, and nongovernmental agencies are working with landowners and farmers to address nutrient reduction, nonpoint source runoff from agricultural lands remains a major source of water quality impairment to freshwater (USEPA 2000) and marine (Turner and Rabalais 1994; Goolsby et al. 1999; Raloff 2004) systems in the United States. Over the last decade, a team of state and federal agencies known as the Mississippi River/Gulf of Mexico Watershed Nutrient Task Force has worked to coordinate nutrient reduction conservation efforts throughout the Mississippi River Basin. Encouraging voluntary, incentive-based adoption of targeted and effective conservation practices is one of the overarching principles outlined in the Task Force's 2008 Gulf Hypoxia Action Plan to achieve conservation goals for the basin (Mississippi River/Gulf of Mexico Nutrient Task Force 2008).

Because nonpoint source nutrient runoff from agricultural lands is not regulated, any adoption of conservation practices will necessarily be voluntary in nature. The success of voluntary programs at achieving sustainable conservation in agricultural landscapes requires effective communication with farmers on what is important, practical, and economically reasonable (e.g., Lockeretz 1990). Although numerous studies have assessed factors that influence voluntary adoption of soil, animal, and nutrient management practices within the United States, few consistently explain the adoption of conservation agricultural practices (see reviews by Lockeretz 1990; Knowler and Bradshaw 2007; Prokopy et al. 2008). Utilization of social networks and access to information, however, were positively related to farmer adoption rates (Knowler and Bradshaw 2007; Prokopy et al.2008). Although environmental concerns likely play a part in adoption of conservation practices (e.g., Napier et al. 2000a; Doll and Jackson 2009) economic return to investment has also been identified as a requisite component that encourages adoption of new conservation technologies (Lutz et al. 1984; Napier 2001; Wossink and Osmond 2002; Baerenklau 2005; Doll and Jackson 2009). This perspective posits that farmers are unlikely to adopt conservation production practices that have potential to reduce farm profit without adequate compensatory incentive payments. Collectively, these studies highlight the need to target soil and water conservation efforts that are tailored to reflect the farm economics and environmental conditions associated with local agricultural and best management practices.

Reduction of nutrient loads in the Gulf of Mexico to levels that will significantly reduce the hypoxic zone will require conservation actions targeted specifically within the Mississippi River Basin states (Mississippi River/Gulf of Mexico Nutrient Task Force 2008). Thus, it is important to understand

Maria Lemke is an aquatic ecologist, and Tim Lindenbaum is an outreach coordinator with the Illinois Chapter of The Nature Conservancy. William Perry is an associate professor in the School of Biological Sciences at Illinois State University. Matt Herbert is an aquatic ecologist with the Michigan Chapter of The Nature Conservancy, and Tim Tear is director of Conservation Science with the New York Chapter of The Nature Conservancy. Jim Herkert is director of the Office of Resource Conservation at the Illinois Department of Natural Resources. 
obstacles and incentives that influence conservation actions among farmers specific to the agricultural watersheds of the Midwest. A number of surveys and questionnaires have been conducted in Midwest agricultural watersheds to better understand what factors influence farmers to adopt conservation practices. Economic (Napier et al. 1984) and structural (Napier et al. 2000b) constraint factors were concluded to be of primary importance in determining adoption of soil and water conservation practices among farmers that were surveyed in multiple watersheds located in Ohio, Iowa, and Minnesota. Napier and Bridges (2002) assessed how exposure to conservation programming influenced implementation of various farming methods, fertilizer application, and conservation practices in two Ohio watersheds based on the hypothesis that exposure to information on new technologies and ideas would develop positive attitudes among participants and ultimately lead to adoption and implementation. However, greater exposure to outreach was not concluded to influence adoption of soil conservation practices (Napier et al. 1984) or implementation of other conservation-based farming practices (Napier and Bridges 2002). In fact, Napier and Bridges (2002) concluded that outreach efforts had only a small impact on farm practices, such that the benefits of outreach did not justify its cost.

Our approach is unique from other studies in that we used a multiyear survey to assess how varying intensity levels of outreach influenced farmers' perceptions and adoption of conservation practices. Although significant progress has been made in the analyses of factors that influence adoption of conservation technologies (e.g., see reviews by Knowler and Bradshaw 2007; Prokopy et al. 2008), we are unaware of any studies that have used this multiyear-outreach approach to evaluate effects of outreach on the adoption of conservation practices. By conducting surveys "before" and "after" targeted outreach, a more direct measure of the influence of outreach on farmers' knowledge and implementation of best management practices (BMPs) can be assessed over time. We evaluated if outreach increased familiarity and participation with USDA cost-share programs that were already widely promoting BMPs (e.g., conservation tillage, stream buffers, grassed waterways) and several less widely used conservation practices (e.g.,

\section{Figure 1}

Map of the Mackinaw River watershed in central Illinois, showing counties and watersheds that were surveyed. Surveys were conducted during 2000 and 2003 in Bray Creek and Henline Creek watersheds.

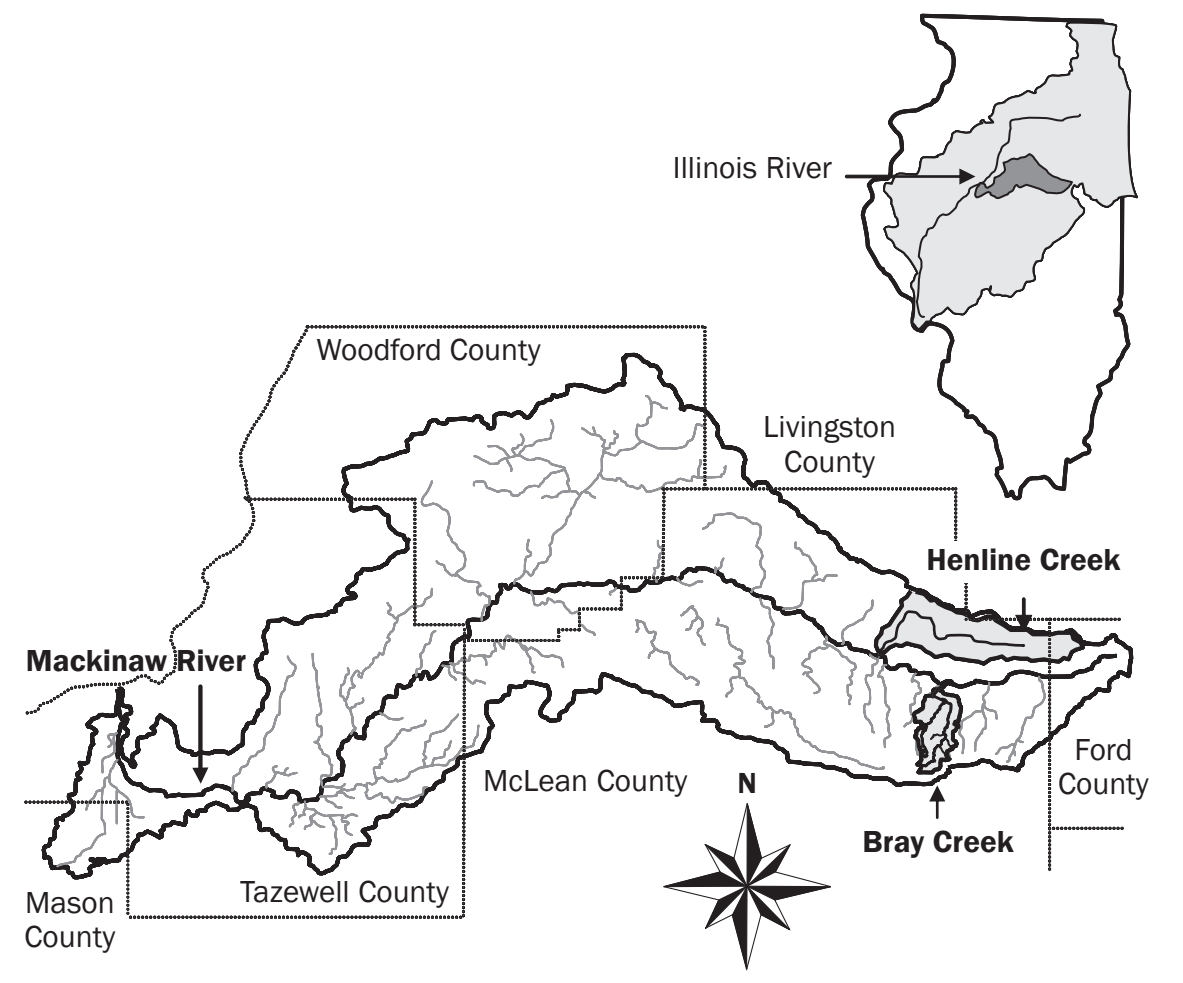

constructed wetlands). We also obtained information from our surveys on the general use of nitrogen fertilizers by farmers in terms of nitrogen forms, application rates, and timing because excess nitrogen runoff from fertilizer use has been identified as a major water quality concern for the Mississippi River basin and the Gulf of Mexico (USEPA 1992; McIsaac et al. 2001; Alexander et al. 2008). In order to implement effective conservation practices for freshwater resources within watersheds, it is important to increase farmer awareness of existing threats to aquatic systems and the conservation practices that can remedy those threats (Lockeretz 1990; Propoky et al. 2008). We hypothesized that outreach would increase awareness of conservation concerns among farmers and would result in measurable increases in conservation-oriented farming practices and use of existing cost-share programs.

Specific objectives of the present study were to document (1) general farming methods used by area farmers, (2) changes in farm and conservation practices during the four-year study, and (3) incentives and disincentives that influenced farmers' decisions to enroll in USDA cost-share programs and implement BMPs. Surveys and outreach in this study were conducted over a four-year period as part of a more comprehensive seven-year study that measured how outreach influenced implementation of BMPs and subsequent effects of BMPs on the ecological integrity of a 4,000 ha $(10,022$ ac) watershed within the Mackinaw River, Illinois (Lemke et al. n.d.).

\section{Methods and Materials}

Study Site. Outreach and surveys were conducted between 2000 and 2003 in the watersheds of Bray Creek and Henline Creek located in the headwater reaches of the upper Mackinaw River in McLean County near Colfax, Illinois (figure 1). The Mackinaw River watershed covers portions of six counties across central Illinois and is the fourth largest tributary to the Illinois River system. Approximately $90 \%$ of the 295,000 ha $(728,320 \mathrm{ac})$ watershed is classified as agricultural with alternate row crop production of corn (Zea mays L.) and soybeans (Glycine $\max$ L.) accounting for $75 \%$ of all land cover (IDNR 1997). Subwatersheds in the headwater areas of the Mackinaw River watershed have been most heavily converted 
with $80 \%$ to $93 \%$ of the land currently in row crop agriculture. Poor drainage in much of the watershed has resulted in the installation of subsurface drainage tile systems that remove excess water from the soil profile and discharge directly into adjacent streams. Soils in the watershed consisted primarily of loess-covered glacial till sediments of the Wisconsin Episode characterized by terminal moraines cutting diagonally across the county from northwest to southeast (USDA NRCS 1998).

Bray Creek and Henline Creek were representative of most headwater watersheds in the subbasin in that they were primarily agricultural and had highly channelized streams with narrow stream buffers and very few trees. Soils consisted of silt-loam mesic composition of Parr-Lisbon-Drummer association in Bray Creek and the lower portion of Henline Creek watersheds and ChenoaDrummer-Graymont association in the upper portion of Henline Creek (USDA NRCS 1998).

Outreach Methods. With the majority of the watershed in agriculture, any attempts to influence conservation practices needed to be approached through the farming community. We developed partnerships with the McLean County Soil and Water Conservation District, McLean County Natural Resources Conservation Service (NRCS), University of Illinois Extension, the Illinois Natural History Survey, the Mackinaw River Watershed Council (a citizen-based conservation group), and a group of local landowners and farmers. These groups provided knowledge specific to the study area about farming practices and conservation needs.

A local landowner and farmer from the area worked with partners to coordinate and conduct the outreach programs from 2000 to 2003. Programs differed between the two watersheds in terms of the levels of intensity at which outreach efforts were conducted. Both watersheds received outreach at intensity levels that might typically be available through the county-level NRCS. In these watersheds, we used individual mailings of flyers and newsletters to provide information on conservation programs and conducted several county-wide community workshops, field demonstrations, and tours. Two county-wide workshops were conducted that promoted strip-till farming practices, and one workshop was offered that promoted prairie restoration, wildlife food plots, and prescribed burning. Two county-wide tours were conducted using Environmental Quality Incentives Program education funds that emphasized habitat restoration (e.g., wetlands, tree plantings, native prairie), conservation practices (e.g., stream buffers, ponds, no-till), and available incentives through the Environmental Quality Incentives Program. In addition, a countywide open house was held at a local USDA Service Center to promote federal and statefunded cost-share programs. Outreach efforts promoted two incentive programs that were available through the Conservation Practices Program (CPP) for strip-till farming practices and grassed waterway construction. During 2000 and 2001, CPP funded a countywide program that paid $\$ 25 \mathrm{ha}^{-1}\left(\$ 10 \mathrm{ac}^{-1}\right)$ to producers that adopted strip-till farming methods on 16 ha $(40 \mathrm{ac})(2000)$ or $32 \mathrm{ha}(80$ ac) (2001) parcels of land that had not previously been farmed using these practices. In 2001 and 2002, outreach efforts promoted additional CPP county-wide funding of a 60-40 cost-share program to promote construction of grassed waterways.

To determine if additional implementation would result from a high-intensity outreach effort, the outreach coordinator visited each landowner and farmer in the Bray Creek watershed to discuss available conservation programs. Information was distributed during these visits on the availability and economic incentives of costshare programs, including the CPP, the Environmental Quality Incentives Program, the Conservation Reserve Program, and the Conservation Reserve Enhancement Program. Two workshops were conducted specifically for Bray Creek producers to demonstrate the required management techniques and equipment for no-till farming. Two tours were also organized to demonstrate the use of constructed wetlands for reducing nutrient transport from farmland to adjacent streams and rivers. In 2001, landowners and producers in Bray Creek were offered $\$ 25 \mathrm{ha}^{-1}\left(\$ 10 \mathrm{ac}^{-1}\right)$, in addition to the CPP payments of $\$ 25 \mathrm{ha}^{-1}$, to adopt striptill farming methods on 32 ha $(80 \mathrm{ac})$ parcels that had not previously been farmed using strip-till practices.

Survey Methods and Analyses. Landowner surveys were conducted in Bray Creek and Henline Creek watersheds in 2000 (preoutreach) and again during 2003 (postoutreach).
Survey questions were developed based on those used in a broader survey conducted across the entire Mackinaw River watershed by The Kitchens Group (2004). Watershed surveys were conducted by a local retired farm manager facilitated by McLean County NRCS and McLean County Soil and Water Conservation District. During 2000 and 2003, requests were mailed to all landowners and producers in each watershed inquiring as to their willingness to be interviewed. In 2000, a total of 41 landowners and producers responded and were interviewed about their use of BMPs and their perspectives on conservation and conservation practices (18 Bray Creek, 23 Henline Creek). Thirty-one of the original respondents were available for the survey in 2003 and were reinterviewed to evaluate any changes in their perspectives or application of conservation practices (12 Bray Creek, 19 Henline). Interview participants received a variety of incentives for their cooperation, including fact sheets about available conservation cost-share opportunities, complimentary sweatshirts, and $\$ 50$ compensation.

Only data that were collected from repeated surveys (i.e., 12 in Bray Creek and 19 in Henline Creek) were included in statistical analyses representing $11 \%$ and $10 \%$ of the landowners in each watershed, respectively. It should be noted that the small sample sizes in this study limit the extent that the views expressed in these survey results are representative of landowner operators in other watersheds. Data in which questions required a "yes" or "no" answer were analyzed using Chi-square analyses to determine significant changes in landowner responses from pre- and postoutreach period. Students $t$-tests were used to analyze data in which questions of farming techniques were answered with acreage percentages. Answers to questions that required participants to prioritize answers from a list of possible choices ranging from "most important" to "least important" were ranked from 1 (least important) to either 3,5 , or 6 (most important). Mean rank values were subsequently calculated as the average rank value among all participants within each year and watershed.

\section{Results and Discussion}

Tillage Practices. Use of strip-till/no-till for corn production remained relatively low in both watersheds and did not change during the study, ranging from $17 \%$ and $21 \%$ in 2000 to $17 \%$ and $32 \%$ in 2003 (table 1). Primary 


\section{Table 1}

Results from 2000 and 2003 surveys conducted in two Mackinaw River watersheds in which interviewees were asked to identify their farming practices and the percentage of farmland acres on which they planted genetically modified (GMO) crops during the previous growing season. Numbers for tillage and precision farming methods represent the percentages of interviewees that implemented these methods. Chi-square analyses were used to determine significant differences between tillage and precision farming methods and t-test analyses were used to determine significant differences between the average percentage of acres that were farmed using GMO crops between the two survey years within Bray Creek $(n=12)$ and Henline Creek $(n=19)$ watersheds.

\begin{tabular}{|c|c|c|c|c|c|c|}
\hline \multirow[b]{2}{*}{ Farming practices } & \multicolumn{3}{|c|}{ Bray Creek watershed } & \multicolumn{3}{|c|}{$\underline{\text { Henline Creek watershed }}$} \\
\hline & $2000(\%)$ & $2003(\%)$ & Difference (\%) & $2000(\%)$ & $2003(\%)$ & Difference (\%) \\
\hline \multicolumn{7}{|l|}{ No-till and strip-till $\dagger$} \\
\hline Soybean (no-till) & 25 & 50 & +25 & 53 & 47 & -6 \\
\hline \multicolumn{7}{|l|}{ Fall tillage } \\
\hline Corn & 75 & 58 & -17 & 63 & 53 & -10 \\
\hline \multicolumn{7}{|l|}{ Precision farming } \\
\hline Yield monitor on combine & 58 & 67 & +9 & 47 & 63 & +16 \\
\hline GPS yield mapping & 17 & 33 & +16 & 37 & 26 & -11 \\
\hline GPS grid soil testing & 75 & 88 & +13 & 53 & 58 & +5 \\
\hline Variable rate of limestone application & 58 & 83 & +25 & 47 & 63 & +16 \\
\hline
\end{tabular}

Note: GPS = global positioning system.

† No-till is defined as planting crops without prior seedbed preparation into existing cover crop, sod, or crop residues.

$\ddagger$ Survey did not distinguish between no-till and strip-till for corn production.

$* p<.05$

concerns of cool soil temperatures, slow early growth, and subsequent yield loss declined somewhat from 2000 to 2003 but continued to limit implementation of strip-till/no-till farming practices among corn producers in both watersheds (figure 2). These same concerns were identified by the Conservation Technology Information Center as primary barriers to adoption of no-till corn production among farmers in the Midwest (CTIC 2002). Access to equipment and farm lease requirements were not important deterrents to strip-till/no-till farming in either of the surveys, although there were increased concerns with the additional use of herbicide associated with strip-till/no-till corn production in both watersheds (figure 2). No-till farming was more acceptable for soybean production, with approximately $50 \%$ use by the farmers surveyed in both Henline Creek and Bray Creek by 2003. Cool soil temperatures and slow early growth are not as much of a concern for no-till soybean production since planting typically occurs later in the spring. Fall tillage practices were used more by producers for fields that had been harvested for corn $(53 \%$ to $75 \%)$ rather than soybeans (16\% to $37 \%)$; however, the use of fall till- age among producers declined somewhat for corn and soybeans between 2000 and 2003 in both watersheds (table 1). In general, precision farming techniques increased over time in both watersheds; however, reductions in variable nitrogen application rates were reported from both watersheds as was a reduced application of global positioning system yield mapping in the Henline Creek watershed (table 1). Most common precision farming techniques included combine yield monitors, global positioning system methods to conduct soil tests, and variable rate methods for limestone application.

Genetically Modified Crops. Changes in the use of genetically modified (GMO) crops differed for corn and soybeans due to the added benefits for their use with soybeans. Reported use of corn genetically modified with the insect-resistant bacterium Bacillus thuringiensis (Bt corn) remained stable between 2000 (20\% to 35\%) and 2003 (23\% to $37 \%)$. Use of $B t$ corn in these watersheds was somewhat higher than the average percentage of acres planted with Bt corn in Illinois between 2000 (13\%) and 2003 (23\%) (USDA ERS 2010). In contrast, significant increases were observed in the percentage of acreages planted with Roundup Ready (RR) soybeans from 34\% to $68 \%$ in Bray Creek ( $t$-test, $t=-2.08$, degrees of freedom $[\mathrm{df}]=22, p=0.02$, sample size $[n]=12)$ and from $30 \%$ to $63 \%$ in Henline Creek ( $t$-test, $t$ $=-2.31, \mathrm{df}=36, p=0.01, n=19)$. Increased use of RR soybeans among farmers in our study followed a national trend of increased adoption rates for biotech soybeans from $<5 \%$ to $75 \%$ of total soybean acres planted in the United States between 1996 and 2003 (Shoemaker et al. 2003) and were similar to increased acreages planted with RR soybeans in Illinois between 2000 (44\%) and 2003 (77\%) (USDA ERS 2010). Potential benefits from adopting RR soybeans include increased yields and the simplification and reduced costs of weed management (e.g., Fernandez-Cornejo and McBride 2000; Lin et al.2001; USDA ERS 2002). More effective herbicide treatments may be especially beneficial for farmers that use no-till production practices (Fernandez-Cornejo and McBride 2002). Thus, the combination of increased adoption of no-till farming and the use of RR soybeans observed in these watersheds likely reflected a larger trend within farming 
communities rather than our localized outreach efforts.

Nitrogen Application. Nitrogen application patterns were similar in both watersheds, with approximately $50 \%$ of producers reporting some decrease in application rates and the other $50 \%$ reporting no change between 2000 and 2003 (table 2). In 2000, anhydrous ammonia and urea-ammonium nitrate were the two major forms of nitrogen used by producers in both watersheds. Anhydrous ammonia is a comparatively inexpensive source of nitrogen as fertilizer, and its consistent use among farmers in this study reflected its widespread popularity and use for corn production (e.g., Shankar et al. 2000). Although ammonium nitrate may be a more expensive fertilizer than anhydrous ammonia in terms of cost per pound of nitrogen, this form of fertilizer was still used by approximately $50 \%$ of the farmers surveyed in 2003. Application of diammonium phosphate increased significantly in Bray Creek (chi-square analyses $\left[\chi^{2}\right]=6.171, p<0.02$, df $=1, n=12)$ and Henline Creek $\left(\chi^{2}=10.270\right.$, $p<0.01, \mathrm{df}=1, n=19)$ between the two surveys, becoming one of the major reported nitrogen sources used in both watersheds in 2003 (table 2).

Producers significantly increased their use of the University of Illinois Extension in both Bray Creek (42\% to $83 \%)\left(\chi^{2}=4.444\right.$, $p<0.05, \mathrm{df}=1, n=12)$ and Henline Creek $(32 \%$ to $63 \%)\left(\chi^{2}=3.80,0.10>p>0.05\right.$, $\mathrm{df}=1, n=19)$ as information sources for nitrogen application (table 2). Bray Creek producers also significantly increased their reliance on individual field tests $(42 \%$ to $75 \%)\left(\chi^{2}=3.884, p<0.05, \mathrm{df}=1, n=12\right)$ and significantly reduced their use of fertilizer dealers $(58 \%$ to $17 \%)\left(\chi^{2}=4.444, p<\right.$ $0.05, \mathrm{df}=1, n=12)$ as sources of nitrogen application information. Significantly higher use of diammonium phosphate among farmers in both watersheds in combination with increased use of fertilizer information from soil tests and Extension services suggests that the addition of phosphorus was determined to be beneficial to crop yields.

Fall nitrogen application is intended to reduce the chances of weather-related delays in nitrogen application and planting during the spring and was a common practice in both watersheds in our study. However, fall fertilizer applications increase the probability of nitrogen loss during fall and spring rains due to the extended time period between

\section{Figure 2}

Results from 2000 and 2003 surveys in two Mackinaw River watersheds in which interviewees were asked to identify obstacles to adopting strip-till/no-till practices for corn production.

Participants ranked obstacles as 1 (not a problem), 2 (minor problem), or 3 (major problem).

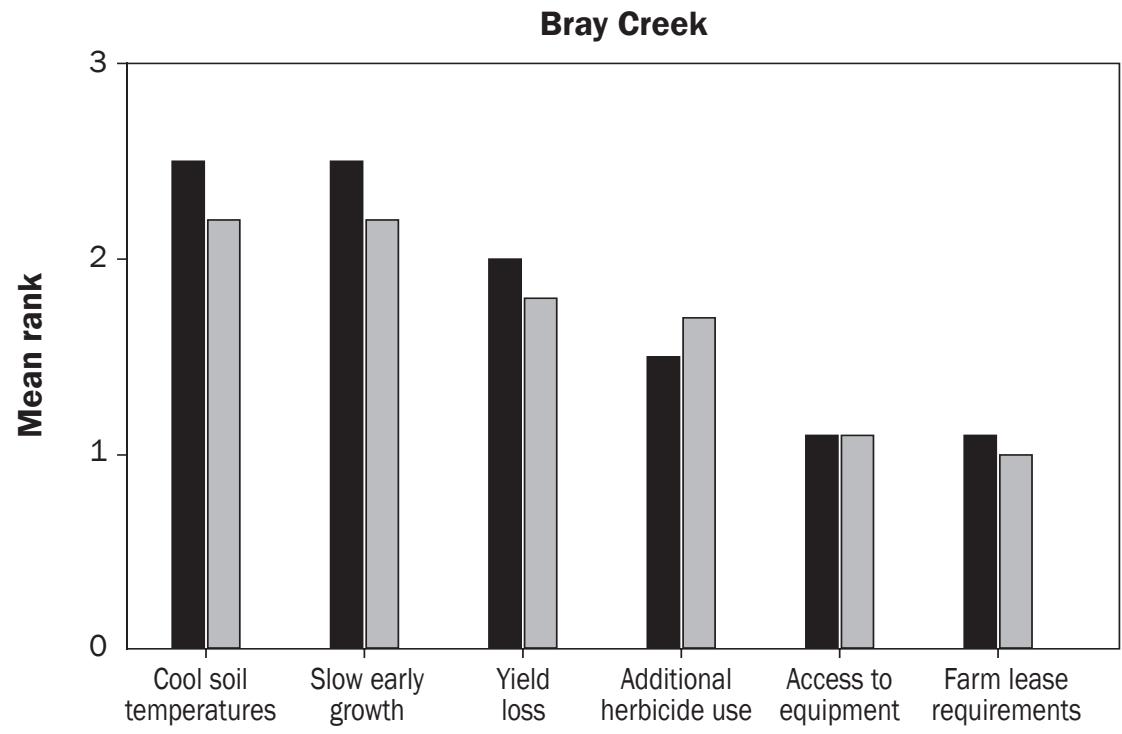

\section{Obstacles to adopting strip-till/no-till farming practices for corn production}

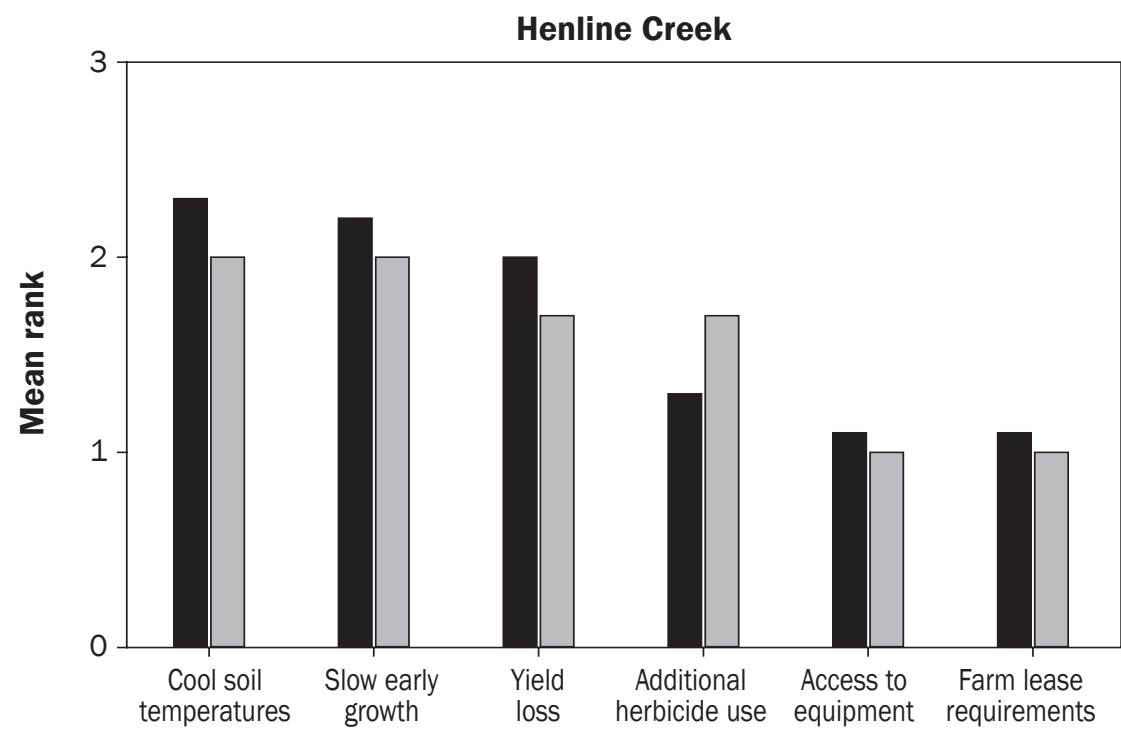

Obstacles to adopting strip-till/no-till farming practices for corn production

\section{Legend

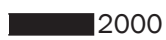 \\ $\square 2003$}

nitrogen application and crop uptake (e.g., Randall and Mulla 2001). In Bray Creek, $75 \%$ of the producers surveyed applied the majority of nitrogen fertilizer they used in the fall, compared to $53 \%$ in Henline Creek (table 2). These percentages agree with survey results of farmers from a nearby subbasin of the Sangamon River in central Illinois, in 


\section{Table 2}

Results from 2000 and 2003 surveys conducted in two Mackinaw River watersheds in which interviewees were asked to identify nitrogen application practices in terms of rates, forms, information sources and methods. Numbers represent the percent of interviewees that responded "yes" to the question. Chi-square analyses were used to determine significant differences in the use of nitrogen forms, information sources and application methods between the two survey years within Bray Creek $(n=12)$ and Henline Creek $(n=19)$ watersheds.

\begin{tabular}{|c|c|c|c|c|c|c|}
\hline \multirow[b]{2}{*}{ Nitrogen practices } & \multicolumn{3}{|c|}{ Bray Creek watershed } & \multicolumn{3}{|c|}{ Henline Creek watershed } \\
\hline & $2000(\%)$ & $2003(\%)$ & Difference (\%) & $2000(\%)$ & $2003(\%)$ & Difference (\%) \\
\hline \multicolumn{7}{|l|}{ Changes in nitrogen application rates } \\
\hline Decreased & 42 & 50 & & 53 & 53 & \\
\hline No change & 50 & 50 & & 42 & 47 & \\
\hline \multicolumn{7}{|l|}{ Nitrogen forms } \\
\hline Diammonium phosphate (DAP) & 17 & 67 & $+50 *$ & 32 & 84 & $+52 * *$ \\
\hline Urea-ammonium nitrate (UAN 28) & 75 & 50 & -25 & 63 & 53 & -10 \\
\hline Ammonium sulfate & 0 & 8 & +8 & 0 & 5 & +5 \\
\hline \multicolumn{7}{|l|}{ Nitrogen application information sources } \\
\hline University of Illinois Extension & 42 & 83 & $+41 *$ & 32 & 63 & +31 \\
\hline \multicolumn{7}{|l|}{ Nitrogen application methods } \\
\hline Fall application & 75 & 75 & 0 & 53 & 53 & 0 \\
\hline Nitrogen stabilizer/inhibitor & 50 & 50 & 0 & 53 & 37 & -16 \\
\hline Nitrogen side-dress & 17 & 8 & -9 & 21 & 16 & -5 \\
\hline
\end{tabular}

$* p<.05 * * p<.01$

which $75 \%$ of nitrogen fertilizer was applied in the fall (Shankar et al. 2000). No changes in fall nitrogen application practices were reported among survey participants between 2000 and 2003.

Nitrogen stabilizers can be used to minimize loss of nitrogen by reducing nitrification processes that convert ammonium fertilizer to the more leachable nitrate $\left(\mathrm{NO}_{3}^{-}\right)$form. Approximately $50 \%$ of farmers surveyed in Bray Creek used nitrogen stabilizers throughout the study; whereas, the use of stabilizers decreased from 53\% (2000) to 37\% (2003) among producers surveyed in Henline Creek. Another practice that has the potential to reduce nitrogen loss from agricultural fields is side-dress application of nitrogen during early crop growth at concentrations that are based on measures of residual soil $\mathrm{NO}_{3}^{-}$, thus reducing the need for fall application. Research by Jaynes et al. (2004) in central Iowa suggests that adoption of side dressing with late spring nitrogen tests could result in a $\geq 30 \%$ decrease in $\mathrm{NO}_{3}{ }^{-}$concentrations for watersheds where fall nitrogen application is commonly practiced. In our study, however, only $8 \%$ to $21 \%$ of producers surveyed practiced side-dress nitrogen application methods.
Conservation Practices and Programs. A significant increase was observed in the percentage of farmers surveyed that implemented grassed waterways on all of the land that they farmed from $50 \%$ to $92 \%\left(\chi^{2}\right.$ $=5.042, p<0.05, \mathrm{df}=1, n=12)$ in Bray Creek, the watershed that received outreach at a higher intensity (table 3 ). In contrast, the percentage of farmers in Henline Creek that applied grassed waterways where appropriate on all of the land they farmed remained steady at $53 \%$. Although the use of stream buffers doubled from $8 \%$ to $17 \%$ among producers in Bray Creek, these values were low compared to the $\sim 40 \%$ of producers that implemented buffers in Henline Creek. It should be noted that not all producers surveyed in the watershed farmed adjacent to a stream, and thus would not necessarily qualify for stream buffer implementation. Contour farming and terraces were not commonly used in either watershed, ranging from $0 \%$ to $5 \%$ use by the respondents (table 3 ). In contrast, $83 \%$ to $92 \%$ of the producers surveyed in both watersheds practiced conservation tillage (i.e., at least 30\% of residue remaining) on the land that they farmed.
Although participation in most cost-share programs remained low among producers in both watersheds, enrollment for the CPP significantly increased among Bray Creek producers from $33 \%$ to $75 \%$ of those surveyed $\left(\chi^{2}=4.196, p<0.05, \mathrm{df}=1, n=12\right)$, compared to a smaller increase from $32 \%$ to $58 \%$ among those surveyed in Henline Creek (table 4). The CPP was already well known among farmers in both watersheds as a means of cost-share for grassed waterways and striptill farming practices; however, participation in this program prior to outreach was low in both watersheds. Similarly, Kraft et al. (1996) reported that the likelihood of farmers participating in the Water Quality Incentive Program was significantly greater when the level of contact between farmers and NRCS increased, and a review of 55 studies spanning 25 years of literature (Prokopy et al. 2008) showed that increased information and awareness were more likely to positively affect adoption of BMPs. In contrast, Napier and Bridges (2002) reported no significant differences in farm production systems between two watersheds that received intensive versus no outreach by using a broader scale "adoption index" that was a compos- 
Table 3

Results from 2000 and 2003 surveys conducted in the Mackinaw River watersheds in which interviewees were asked to identify the types of conservation and farming practices they used on the farmland that they operated. Numbers represent the percent of participants that used each of the respective practices on all of the land that they farmed. Chi-square analyses were used to determine significant differences between survey years of the number of interviewees within Bray Creek $(n=12)$ and Henline Creek $(n=19)$ watersheds that used conservation practices on all of the farmland on which they operated.

\begin{tabular}{|c|c|c|c|c|c|c|}
\hline \multirow[b]{2}{*}{ Conservation practice } & \multicolumn{3}{|c|}{ Bray Creek watershed } & \multicolumn{3}{|c|}{ Henline Creek watershed } \\
\hline & $2000(\%)$ & $2003(\%)$ & Difference (\%) & $2000(\%)$ & $2003(\%)$ & Difference (\%) \\
\hline Grassed waterway & 50 & 92 & $+42 *$ & 53 & 53 & 0 \\
\hline Stream buffers & 8 & 17 & +9 & 42 & 37 & -5 \\
\hline Terraces & 0 & 0 & 0 & 0 & 5 & +5 \\
\hline Contour farming & 0 & 0 & 0 & 0 & 0 & 0 \\
\hline Conservation tillage $\dagger$ & 83 & 92 & +9 & 89 & 89 & 0 \\
\hline
\end{tabular}

† Conservation tillage was defined as at least $30 \%$ of residue from previous crop remaining on field surface after planting and does not exclude chisel plowing, disking, or cultivation of soybean residue in the spring.

$* p<.05$

ite variable representing weighted impacts of multiple farming practices. Differences in outreach effectiveness assessments may be a matter of the scale at which effectiveness and conservation practices are measured. For instance, Prokopy et al. (2008) suggest that differences may exist among determinants for adoption of specific BMPs versus a larger set of agricultural innovations.

Familiarity of several federal cost-share programs significantly increased among respondents in both watersheds during this study (table 4). Knowledge of the Conservation Reserve Enhancement Program increased significantly from 25\% to $92 \%$ of respondents in Bray Creek $\left(\chi^{2}\right.$ $=10.971, p<0.001, \mathrm{df}=1, n=12)$ and from $47 \%$ to $95 \%$ of respondents in Henline Creek $\left(\chi^{2}=10.364, p<0.01, \mathrm{df}=1, n=\right.$ 19). Similarly, there was an increased familiarity of the Wetland Reserve Program in both Bray $\left(\chi^{2}=6.316, p<0.02, \mathrm{df}=1, n\right.$ $=12)$ and Henline $\left(\chi^{2}=4.471, p<0.05, \mathrm{df}\right.$ $=1, n=19)$ watersheds. In contrast, awareness of the Illinois Department of Natural Resources Conservation 2000 (C2000) state program declined significantly in both Bray $\left(\chi^{2}=10.971, p<0.001, \mathrm{df}=1, n=12\right)$ and Henline $\left(\chi^{2}=4.471, p<0.05, \mathrm{df}=1, n=19\right)$ watersheds. By 2003, the majority of producers surveyed in both watersheds was aware of existing federal programs and was not interested in obtaining any additional information (table 4). The primary source of information for producers in the two watersheds about government cost-share programs was the county-level NRCS. Approximately 50\% of the producers interviewed in Bray Creek also used the county-level soil and water conservation district throughout the study; however, there was a significant decrease in the use of this resource among producers in Henline Creek from $53 \%$ to $21 \%\left(\chi^{2}=\right.$ $4.071, p<0.05, \mathrm{df}=1, n=19)$. Information from neighbors or local contractors was used increasingly in both watersheds, and a significant increase was reported among producers in Bray Creek from $8 \%$ to $58 \%\left(\chi^{2}=6.750\right.$, $p<0.01, \mathrm{df}=1, n=12$ ).

Primary disincentives among farmers to enroll in cost-share programs were consistently associated with the inconvenience of too many program changes and the complexity of application processes (figures $3 \mathrm{a}$ and $3 \mathrm{~b}$ ). Additional deterrents included the untimely application period that coincided with spring planting and fall harvesting and a potential loss of revenue associated with implementing new conservation practices. Producers were slightly less concerned about potential loss of productive land, inconsistent information, and whether funding was provided by private or governmental agencies. Financial assistance and technical assistance provided in a timely manner were considered to be major incentives to farmers in both watersheds should they enroll in costshare programs (figures $3 \mathrm{c}$ and $3 \mathrm{~d}$ ).

Perceptions on Freshwater Conservation. Producers surveyed in both watersheds considered excess sediment and pollution the two primary threats to local streams and rivers during this study and became increasingly concerned with local flooding between 2000 and 2003 (figure 4a). Flooding concerns were likely related to near-record rainfalls in the spring of 2002 that resulted in flooding of numerous streams and rivers in Illinois. Habitat loss ranked lower among perceived threats to the watershed, although awareness did increase among producers in Bray Creek during the study. Outreach efforts may have resulted in the observed decline of concern in both watersheds about the lack of public interest as a threat to local streams and the Mackinaw River.

Overall, there were no changes in producers' perceptions of what conservation practices were most effective at reducing threats to the watersheds (figure $4 \mathrm{~b}$ ). Stream buffers were considered by producers in both watersheds as the most important conservation practice that would decrease threats to local streams and the larger watershed. Streambank stabilization was also thought to be of high importance by producers in Bray Creek, although this practice was considered to be somewhat less effective by Henline Creek producers. Nutrient management and expansion of no-till farming practices were considered somewhat effective at reducing threats to watersheds (figure $4 \mathrm{~b}$ ) and were of major interest among producers in both watersheds (figure 4c). Preservation of wetlands or floodplain habitats was perceived as the least effective measure to reduce threats to local streams and the larger watershed (figure 4b)

Intensive outreach efforts in Bray Creek appeared to increase awareness and interest among producers to learn more about multiple conservation practices (figure 4c). Producers in Henline Creek initially expressed higher interest in most conservation practices than Bray Creek producers; however, interest levels were similar by 2003 . Interest in carbon sequestration increased in both watersheds, and Bray Creek producers showed additional interest in learning more about nutrient management, water table management, and native vegetation (figure 4c). Although there was some interest in wetlands among producers, there was 
Table 4

Results from 2000 and 2003 surveys conducted in two Mackinaw River watersheds in which interviewees were asked about their participation, familiarity, and interest in government-funded conservation programs and their primary information sources for technical and financial support related to implementation of conservation practices. Numbers represent the percent of landowners that responded positively. Chi-square analyses were used to determine significant differences in interviewees' answers between the two survey years within Bray Creek $(n=12)$ and Henline Creek $(n=19)$ watersheds.

\begin{tabular}{|c|c|c|c|c|c|c|}
\hline \multirow[b]{2}{*}{ Survey topic } & \multicolumn{3}{|c|}{ Bray Creek watershed } & \multicolumn{3}{|c|}{ Henline Creek watershed } \\
\hline & $2000(\%)$ & $2003(\%)$ & Difference (\%) & $2000(\%)$ & $2003(\%)$ & Difference (\%) \\
\hline \multicolumn{7}{|l|}{ Participation in programs } \\
\hline WRP & 8 & 17 & +9 & 0 & 5 & +5 \\
\hline SSRP & 0 & 8 & +8 & 21 & 11 & -10 \\
\hline CPP & 33 & 75 & $+42 *$ & 32 & 58 & +26 \\
\hline IEPA 319 & 0 & 0 & 0 & 0 & 0 & 0 \\
\hline C2000 & 0 & 0 & 0 & 0 & 0 & 0 \\
\hline \multicolumn{7}{|l|}{ Familiarity with programs } \\
\hline CREP & 25 & 92 & $+67 * * *$ & 47 & 95 & $+48 * *$ \\
\hline WRP & 58 & 100 & $+42 *$ & 79 & 100 & $+21 *$ \\
\hline $\mathrm{C} 2000$ & 75 & 8 & $-67 * * *$ & 79 & 32 & $-47 * *$ \\
\hline \multicolumn{7}{|l|}{ Interest in additional information } \\
\hline CREP & 25 & 0 & -25 & 16 & 0 & -16 \\
\hline WRP & 0 & 0 & 0 & 5 & 0 & -5 \\
\hline SSRP & 0 & 0 & 0 & 0 & 0 & 0 \\
\hline $\mathrm{CPP}$ & 8 & 0 & -8 & 11 & 0 & -11 \\
\hline CRP & 17 & 0 & -17 & 5 & 0 & -5 \\
\hline IEPA 319 & 0 & 0 & 0 & 5 & 0 & -5 \\
\hline C2000 & 17 & 0 & -17 & 11 & 0 & -11 \\
\hline \multicolumn{7}{|l|}{ Sources of information } \\
\hline \multicolumn{7}{|c|}{$\begin{array}{l}\text { CREP }=\text { Conservation Reserve Enhancement Program. WRP }=\text { Wetlands Reserve Program. SSRP }=\text { Streambank Stabilization and Restoration Pro- } \\
\text { gram. CPP }=\text { Conservation Practices Program. CRP }=\text { Conservation Reserve Program. IEPA } 319=\text { Illinois Environmental Protection Agency-Section } \\
319 \text { Program. C } 2000=\text { Illinois Department of Natural Resources Conservation } 2000 \text { Ecosystem Program. NRCS }=\text { Natural Resource Conservation } \\
\text { Service. SWCD }=\text { Soil and Water Conservation District. U of I Extension = University of Illinois Extension Service. } \\
\star p<.05 * * p<.01 * * * p<.001\end{array}$} \\
\hline
\end{tabular}

not much incentive to learn more about this practice. Overall, native vegetation ranked lowest among practices that producers were interested in learning more about.

\section{Summary and Conclusions}

Survey results suggest that more intensive outreach efforts, such as one-on-one landowner visits and localized workshops and tours, can increase adoption of conservation practices associated with cost-share programs. Outreach efforts in our study were directed towards increasing (1) farmers' familiarity with and participation in existing cost-share programs, (2) adoption of conservation practices, and (3) general awareness among farmers of the agricultural threats to the Mackinaw River watershed. County-wide outreach did increase familiarity of several federal costshare programs (i.e., Conservation Reserve Enhancement Program, Wetland Reserve Program) among farmers in both watersheds; however, actual participation in these programs did not increase in either water- shed. In contrast, participation in the CPP program was significantly increased among farmers in the watershed that received more intensive outreach, even though farmers in both watersheds were already well aware of this cost-share opportunity. Participation in the CPP included a significant increase in the percent of farmers that implemented grass waterways and a two-fold increase in no-till farming for soybean production.

There is an apparent need to increase outreach efforts to include more innova- 


\section{Figure 3}

Results from 2000 and 2003 surveys conducted in two Mackinaw River watersheds in which interviewees were asked their concern with using cost-share programs in (a) Bray Creek, (b) Henline Creek and what types of support they would require to enroll in cost-share programs in (c) Bray Creek and (d) Henline Creek. Participants ranked concern level and amount of needed support as 1 (not important), 2 (somewhat important), or 3 (very important).

(a)

ํㅓㄹ
Bray Creek

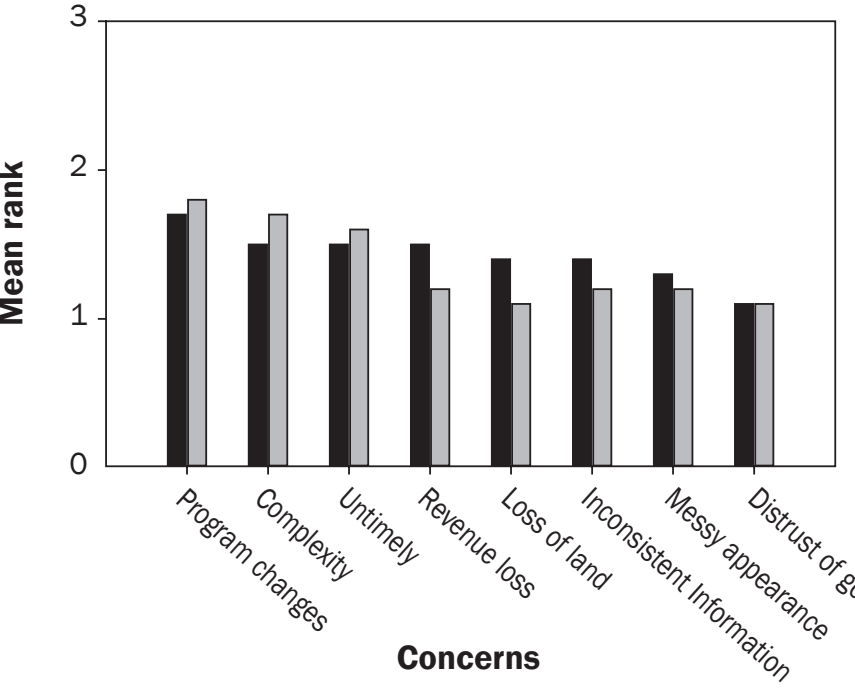

(c)

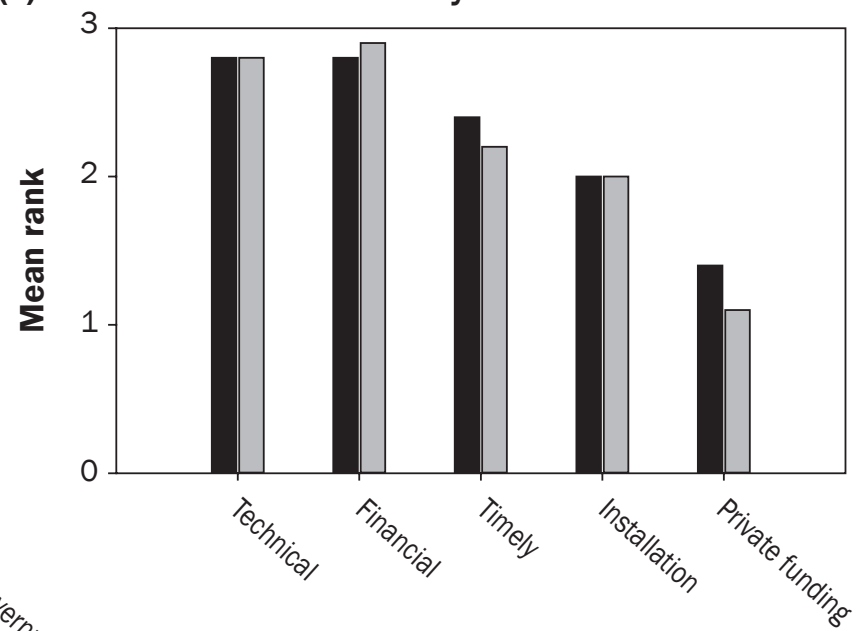

Types of support needed (b)

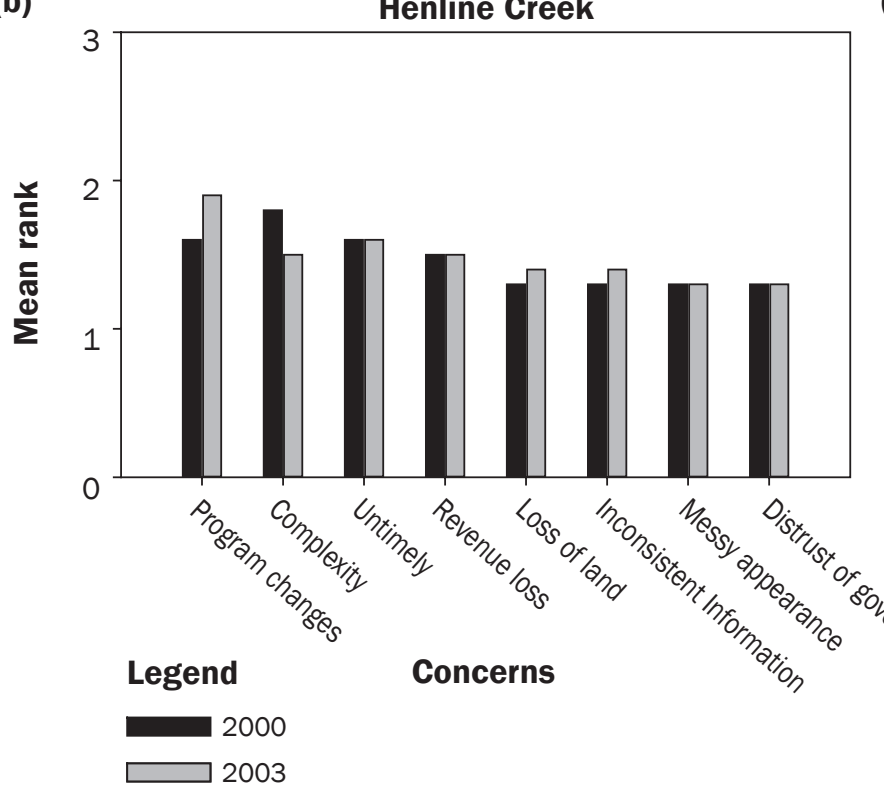

(d)

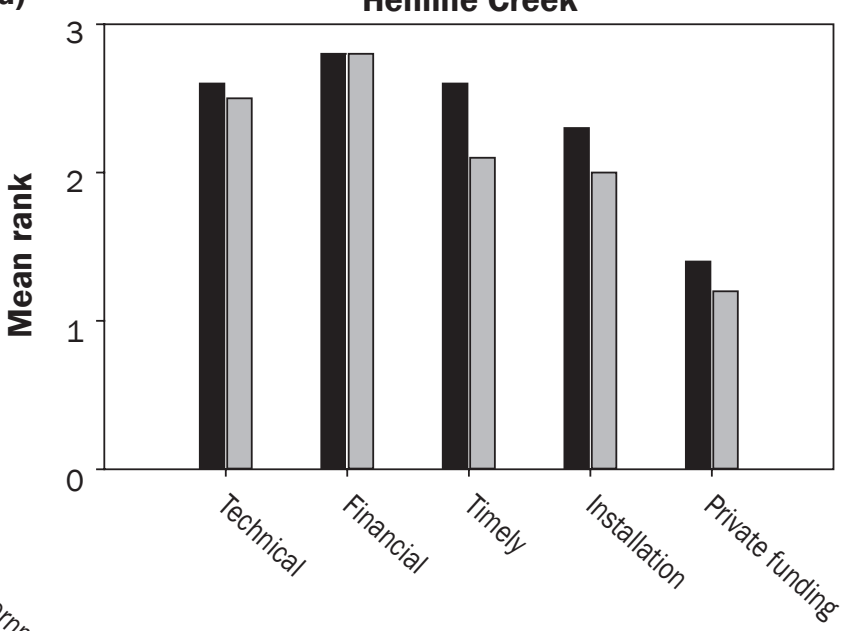

Types of support needed tive conservation practices that will reduce agricultural impacts locally and nationally. Throughout the study, farmers in both watersheds were aware of excessive sediment and pollution in the Mackinaw River and considered reductions in streambank erosion and surface water runoff from agricultural fields to be appropriate solutions. However, large sources of agricultural runoff enter the
Mackinaw River through underground tile drainage systems that outlet into tributary streams, reducing the effectiveness of surface water retention practices, such as stream buffers and grassed waterways (Lemke et al. n.d.). Transport of nitrogen and phosphorus through tiles is substantial (e.g., David et al. 1997; Xue et al. 1998) and can be even greater in some no-till systems with sub- surface drainage (Tan et al. 1998; Yates et al. 2006), although this is not always the case (e.g., Randall and Iragavarapu 2005; Zhu et al. 2003). Constructed tile-retention wetlands can be very effective at retaining tile water and reducing nutrient export from agricultural lands (Kovacic et al. 2000; Woltemade 2000; Kovacic et al. 2006; Iovanna et al. 2008). However, in our study, wetlands were 


\section{Figure 4}

Results from 2000 and 2003 surveys conducted in two Mackinaw River watersheds in which interviewees were (a) asked to rank threats to local rivers and streams, (b) practices they believed were most effective at addressing those threats, and (c) which of these practices they would be interested in learning more about. Rankings range from 1 (least important) to either 5 (a,b) or 6 (c) (most important).

(a)

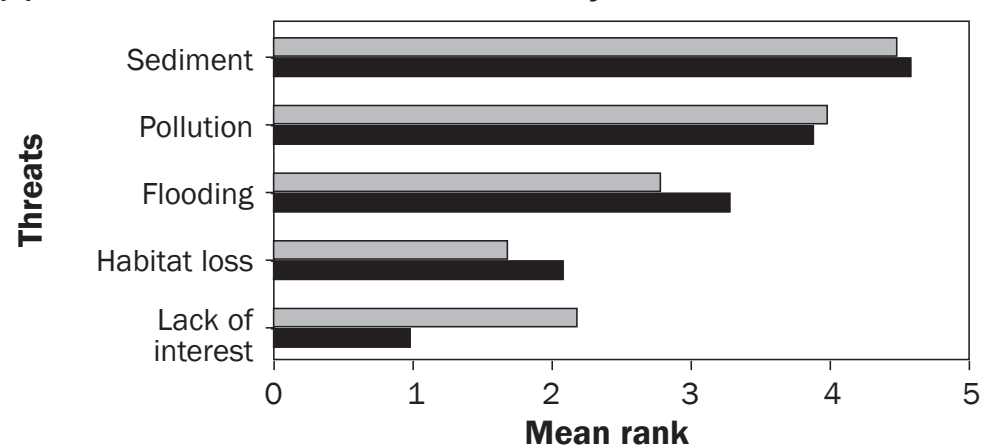

(b)

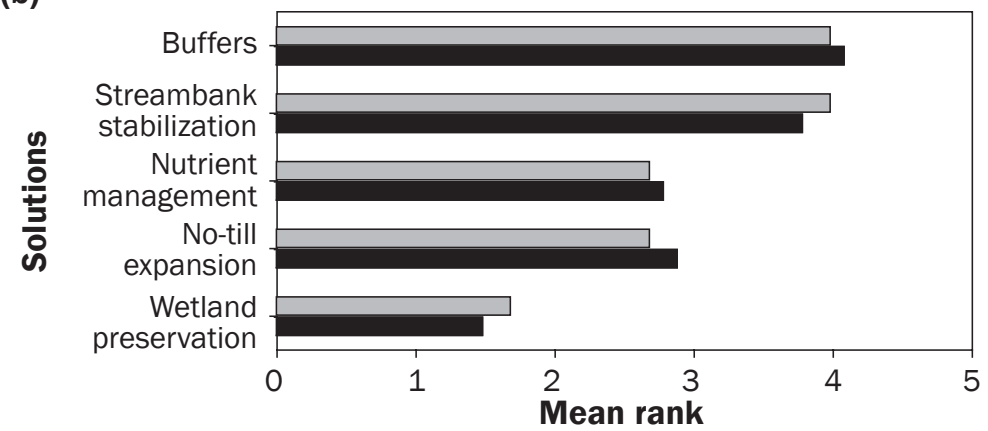

(c)

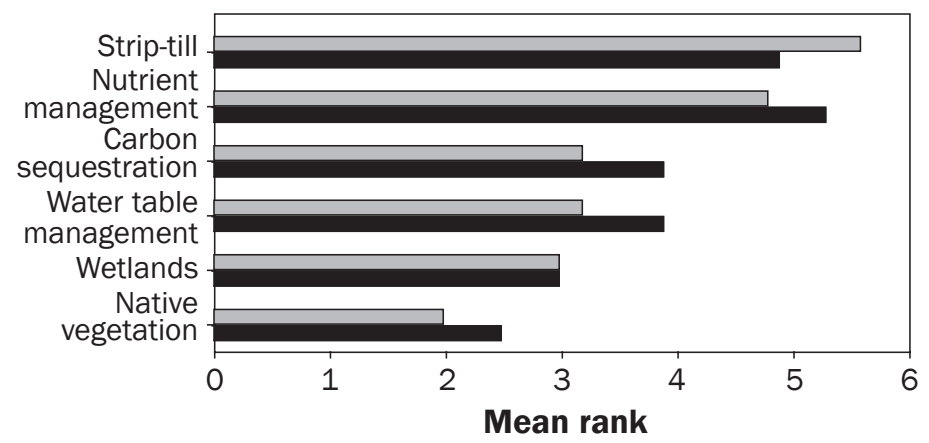

Legend

Bray Creek
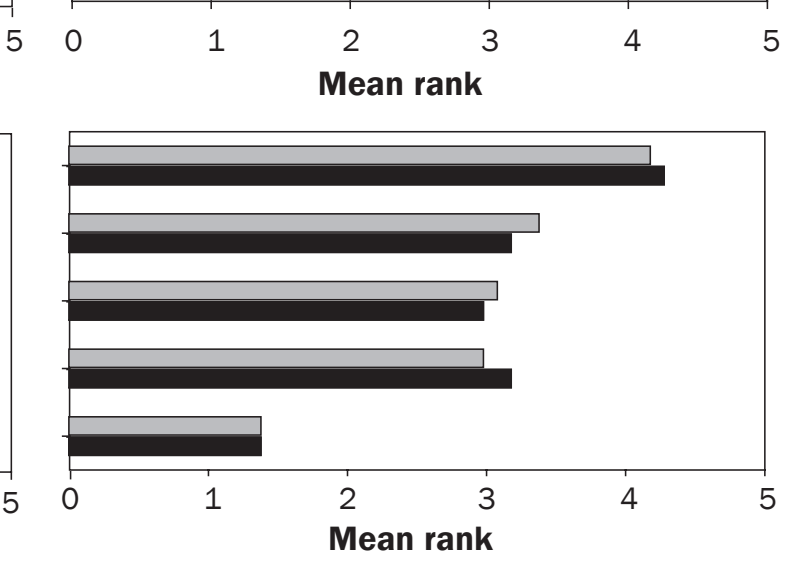

0

Henline Creek
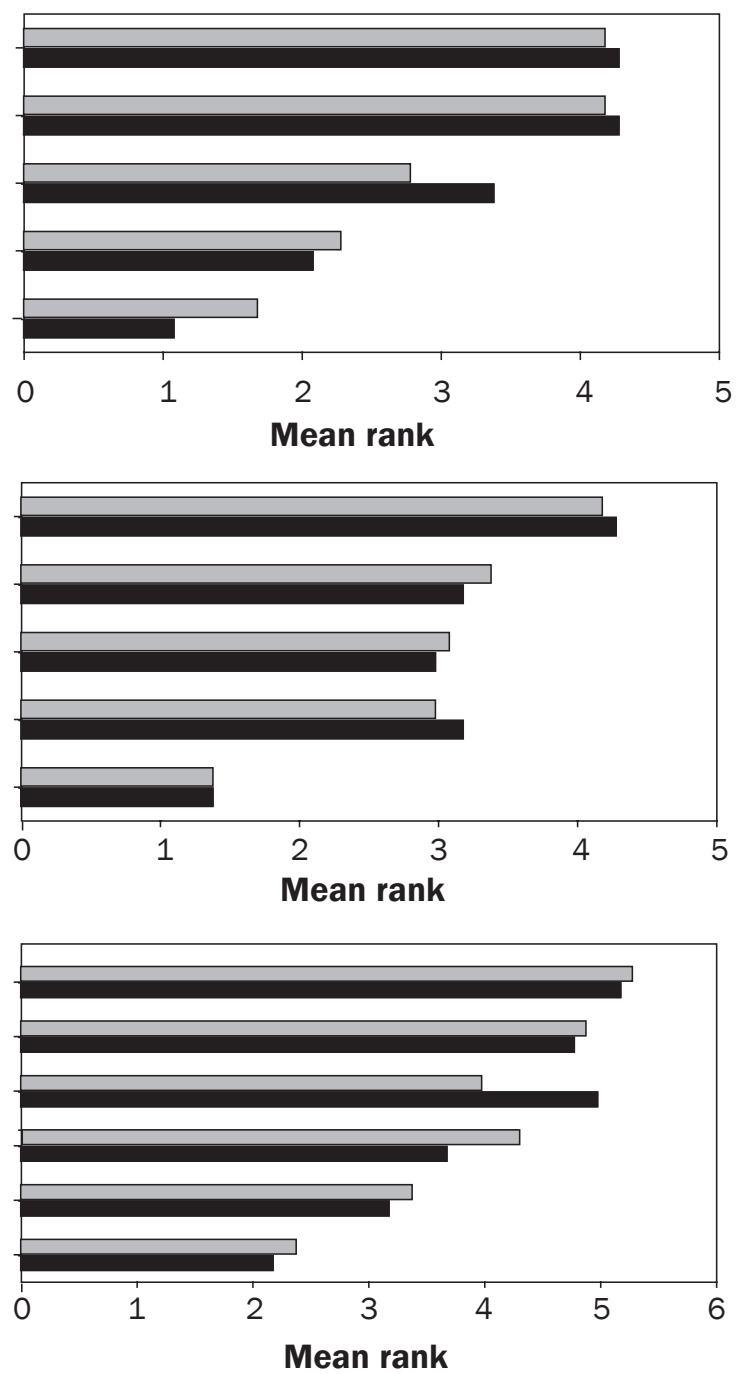

identified by farmers in both watersheds as relatively ineffective conservation practices. In contrast, a recent report from a US Environmental Protection Agency Science Advisory Board panel noted the effectiveness of wetlands at reducing nitrogen and suggested targeted wetland restoration as a promising approach to effectively reducing nutrient pollution from heavily tile-drained agricultural lands (USEPA 2007). In Illinois alone, there is an estimated 11.6 million ac $(4,694,353.4 \mathrm{ha})$ of tile-drained land (Sugg 2007 ) and a loss of $89 \%$ to $99.5 \%$ of his- torical wetland habitat, contributing to an average of $59 \%$ of historical wetland loss among the states that border the Mississippi River (Mitsch and Gosselink 1993; Devine et al. 2008). Clearly, more effective outreach is needed to increase the awareness of wetlands as an effective conservation practice to mitigate tiled-drained agricultural runoff in the Midwest.

Even with outreach, some farming practices that are environmentally detrimental may not change appreciably. Conflicting goals of environmental protection and streamlin- ing farming efficiency are especially apparent with fall application of nitrogen fertilizer. Fall application was a common practice in both watersheds throughout the study and is a traditional method of nitrogen application in the Midwest (Dinnes et al. 2002; Napier and Bridges 2002; Randall and Sawyer 2008). Randall and Mulla (2001) reported 36\% higher loss of nitrogen through tile drainage waters when fall versus spring applied. Whereas, Gentry et al. (2000) reported 70\% higher loss of nitrate in tile drainage following winter application. Even with substantial 
loss of nitrogen, many farmers continue fall application to minimize time demand in the spring, reduce risk of soil compaction, and prevent weather-related delays in spring fertilizer application and planting (Dinnes et al. 2002). There is a general assumption that fall application methods will be slow to change and that additional BMPs, such as wetlands, cover crops, and nutrient management will be needed to appreciably reduce nitrogen losses to surface waters (Randall and Sawyer 2008).

Technical and financial assistance provided in a timely manner were considered to be major incentives to farmers in both watersheds should they enroll in cost-share programs. High use of the NRCS by farmers in our study suggests that outreach efforts designed to increase the capacity of local conservation professionals to provide this type of assistance can have positive effects on implementation of conservation practices. However, staff time and economic costs associated with outreach and implementation can be substantial. Napier and Bridges (2002) suggest that the additional time and economic resources required to conduct intensive outreach will not result in substantial returns of BMP implementation and suggest alternative approaches for allocating conservation resources, such as permanent set-aside lands, reliance on traditional outreach programs, and development of public policies. Several studies have identified social networks as important vectors for providing information (Habron 2004; Prokopy et al. 2008) and suggest an alternative approach of using landowners as the dissemination agent rather than the local conservation agency staff (Coughenour 2003). Outreach teams comprised of stakeholders and local conservation agency staff coordinated at subwatershed scales may provide a forum for interchange of conservation ideas among farmers. There remains a need to test the concept that these integrated teams can maximize outreach effectiveness and reduce demands on the limited staff time of local conservation agencies. Conservation efforts designed to develop effective outreach and implementation programs are a necessary component towards achieving the goal of reducing nutrient exports to the Mississippi River and Gulf of Mexico from tile-drained agricultural lands of the Midwest.

\section{Acknowledgements}

We thank Kent Bohnhoff, a district conservationist of the McLean County Natural Resources Conservation Service, and Jim Rutherford, a watershed conservationist, and David Bishop, a resource conservationist, for McLean County Soil and Water Conservation District for their assistance and dedication to this project. Peter Kareiva, chief scientist for The Nature Conservancy, Joe Fargione, lead scientist for the North American Region for The Nature Conservancy, and Meredith Cornett, director of Conservation Science for Minnesota and the Eastern Dakotas for The Nature Conservancy, and two anonymous reviewers provided many helpful comments on earlier drafts of this manuscript. Funding for this study was provided by the Kellogg Family Foundation.

\section{References}

Alexander, R.B., R.A. Smith, G.E. Schwarz, E.W. Boyer, J.V. Nolan, and J.W. Brakebill. 2008. Differences in phosphorus and nitrogen delivery to the Gulf of Mexico from the Mississippi River Basin. Environmental Science and Technology 42(3):822-830.

Baerenklau, K.A. 2005. Toward an understanding of technology adoption: Risk, learning, and neighborhood effects. Land Economics 81(1):1-19.

CTIC (Conservation Technology Information Center). 2002. Economic Benefits with Environmental Protection: Notill and Conservation Buffers in the Midwest.

Coughenour, C.M. 2003. Innovating conservation agriculture:The case of no-till cropping. Rural Sociology 68:278-304.

David, M.B., L.E. Gentry, D.A. Kovacic, and K.M. Smith. 1997. Nitrogen balance in and export from an agricultural watershed. Journal of Environmental Quality 26:1038-1048.

Devine, J., M. Dorfman, and K.S. Rosselot. 2008. Polluting the Mississippi River Basin's Small Streams and Wetlands. Natural Resources Defense Council Issue Paper, Missing Protection, October 2008.

Dinnes, D.L., D.L. Karlen, D.B. Jaynes, T.C. Kasper, J.L. Hatfield, T.S. Colvin, and C.A. Cambardella. 2002. Nitrogen management strategies to reduce nitrate leaching in tile-drained Midwestern soils. Agronomy Journal 94:153-171.

Doll, J.E., and R.D. Jackson. 2009. Wisconsin farmer attitudes regarding native grass use in grazing systems. Journal of Soil and Water Conservation 64(4):276-285, doi:10.2489/jswc.64.4.276.

Fernandez-Cornejo, J., and W. McBride. 2000. Genetically Engineered Crops for Pest Management in U. S. Agriculture: Farm-Level Effects. AER-786. USDA Economic Research Service, Resource Economics Division. April 2000.

Fernandez-Cornejo, J., and W.D. McBride. 2002. FarmLevel Effects of Adopting Genetically Engineered Crops. AIB-762. USDA Economic Research Service.
Economic Issues in Agricultural Biotechnology, Trends and Contributing Factors.

Gentry, L.E., M.B. David, K.M. Smith-Starks, and D.A. Kovacic. 2000. Nitrogen fertilizer and herbicide transport from tile drained fields. Journal of Environmental Quality 29:232-240.

Goolsby, D.A., W.A. Battaglin, G.B. Lawrence, R.S. Artz, B.T. Aulenbach, R.P. Hooper, D.R. Keeney, and G.J. Stensland. 1999. Flux and Sources of Nutrients in the Mississippi-Atchafalaya Basin: Topic 3 report for the Integrated Assessment on Hypoxia in the Gulf of Mexico. Silver Spring, MD: NOAA Coastal Ocean Office. NOAA Coastal Ocean Program Decision Analysis Series No 17.

Habron, G.B. 2004. Adoption of conservation practices by agricultural landowners in three Oregon watersheds. Journal of Soil and Water Conservation 59(3):109-115.

IDNR (Illinois Department of Natural Resources). 1997. Mackinaw River Area Assessment, Vol. 1. Publication of the Natural History Survey Division of the Illinois Department of Natural Resources and Critical Trends Assessment Program. Springfield, Illinois.

Iovanna, R., S. Hyberg, and W. Crumpton. 2008. Treatment wetlands: Cost-effective practice for intercepting nitrate before it reaches and adversely impacts surface waters. Journal of Soil and Water Conservation 63(1):14A-15A, doi:10.2489/jswc.63.1.14A.

Jaynes, D.B., D.L. Dinnes, D.W. Meeks, D.L. Karlan, C.A. Cambardella, and T.S. Colvin. 2004. Using the late spring nitrate test to reduce nitrate loss with a watershed. Journal of Environmental Quality 33:669-677.

Kovacic, D.A., M.B. David, L.E. Gentry, K.M. Starks, and R.A. Cooke. 2000. Effectiveness of constructed wetlands in reducing nitrogen and phosphorus export from agricultural tile drainage. Journal of Environmental Quality 29:1262-1274.

Kovacic, D.A., R.M. Twait, M.P. Wallace, and J.M. Bowling. 2006. Use of created wetlands to improve water quality in the Midwest-Lake Bloomington case study. Ecological Engineering 28:258-270.

Knowler, D., and B. Bradshaw. 2007. Farmers' adoption of conservation agriculture: A review and synthesis of recent research. Food Policy 32(1):25-48.

Kraft, S.E., C. Lant, and K. Gillman. 1996. WQIP: An assessment of its chances for acceptance by farmers. Journal of Soil and Water Conservation 51(6):494-498.

Lemke,A.M., M.E.Herbert, K.G. Kirkham,T.T. Lindenbaum, W.L. Perry, T.H. Tear, and J.R. Herkert. n.d. Evaluating agricultural best management practices in Illinois: Stream buffers and grass waterways yield limited benefits. Journal of Environmental Quality. In review.

Lin, W., G.K. Price, and J. Fernandez-Cornejo. 2001. Estimating farm-level effects of adopting herbicidetolerant soybeans. OSC-2001, USDA Economic Research Service. October 2001. 
Lockeretz, W. 1990. What have we learned about who conserves soil? Journal of Soil and Water Conservation 45(5):517-523.

Lutz, E., S. Pagiola, and C. Reiche. 1984. The costs and benefits of soil conservation: The farmer's viewpoint. The World Bank Research Observer 9(2):273-295.

McIsaac, G.F., M.B. David, G.Z. Gertner, and D.A. Goolsby. 2001. Eutrophication: Nitrate flux in the Mississippi River. Nature 414:166-167.

Mississippi River/Gulf of Mexico Watershed Nutrient Task Force. 2008. Gulf Hypoxia Action Plan 2008 for reducing, mitigating, and controlling hypoxia in the Northern Gulf of Mexico and improving water quality in the Mississippi River Basin. Washington DC.

Mitsch, W.J., and J.G. Gosselink. 1993. Wetlands, 2nd ed. New York:Van Nostrand Reinhold.

Napier, T.L. 2001. Soil and water conservation behaviors within the upper Mississippi River Basin. Journal of Soil and Water Conservation 56(4):279-285.

Napier, T.L., and T. Bridges. 2002. Adoption of conservation production systems in two Ohio watersheds: A comparative study. Journal of Soil and Water Conservation 57(4):229-235.

Napier, T.L., J. Robinson, and M. Tucker. 2000a. Adoption of precision farming within three Midwest watersheds. Journal of Soil and Water Conservation 55(2):135-141.

Napier, T.L., C.S. Thraen, A. Gore, and W.R. Goe. 1984. Factors affecting adoption of conventional and conservation tillage practices in Ohio. Journal of Soil and Water Conservation 39(3):205-209.

Napier, T.L., M. Tucker, and S. McCarter. 2000b. Adoption of conservation production systems in three Midwest watersheds. Journal of Soil and Water Conservation 55(2):123-134.

Prokopy, L.S., K. Floress, D. Klotthor-Weinkauf, and A. Baumgart-Getz. 2008. Determinants of agricultural best management practice adoption: Evidence from the literature. Journal of Soil and Water Conservation 63(5):300-311, doi:10.2489/jswc.63.5.300.

Raloff, J. 2004. Dead Waters: Massive oxygen-starved zones are developing along the world's coasts. Science News 165 (23), June 5, 2004.

Randall, G.W., and T.K. Iragavarapu. 2005. Impact of longterm tillage systems for continuous corn on nitrate leaching to tile drainage. Journal of Environmental Quality 24:360-366.

Randall, G.W., and D.J. Mulla. 2001. Nitrate nitrogen in surface waters as influenced by climatic conditions and agricultural practices. Journal of Environmental Quality 30:337-344.

Randall, G.W., and J.E. Sawyer. 2008. Nitrogen application timing, forms, and additives. In Final Report: Gulf Hypoxia and Local Water Quality Concerns Workshop, 72-85. American Society of Agricultural and Biological Engineers, St. Joseph, Michigan.
Shankar, B., E.A. DeVuyst, D.C. White, J.B. Braden, and R.H. Hornbaker. 2000. Nitrate abatement practices, farm profits, and lake water quality: A central Illinois case study. Journal of Soil and Water Conservation 55(3):296-303.

Shoemaker, R., D.D. Johnson, and E. Golan. 2003. Consumer and the future of biotech food in the United States. Economic Research Service, USDA. Amber Waves 1:30-36.

Sugg, Z. 2007. Assessing U.S. Farm Drainage: Can GIS Lead to Better Estimates of Subsurface Drainage Extent? Washington DC: World Resources Institute.

Tan, C.S., C.F. Drury, M. Soultani, I.J. van Wesenbeeck, H.Y.F. Ng, J.D. Gaynor, and T.W. Welacky. 1998. Effect of controlled drainage and tillage on soil structure and tile drainage nitrate loss at the field scale. Water Science and Technology 38:103-110.

The Kitchens Group. 2004. Issue Analysis for Mackinaw, Illinois, French Creek Watershed and Upper St. Joseph Watershed. 2004 report prepared for The Nature Conservancy. Maitland, Florida.

Turner, R.E., and N.N. Rabalais. 1994. Coastal eutrophication near the Mississippi river delta. Nature 368:619-621.

USDA ERS (Economic Research Service). 2002. Microeconomic Impact of Adopting Bioengineered Crops. http://www.ers.usda.gov/publications/aer810/ aer810g.pdf.

USDA ERS. 2010. Adoption of genetically engineered crops in the U.S.: Genetically engineered corn varieties. http://www.ers.usda.gov/Data/BiotechCrops/ ExtentofAdoptionTable1.htm.

USDA NRCS (Natural Resources Conservation Service). 1998. Soil Survey of McLean County, Illinois. Illinois Agricultural Experiment Station Report No. 159.

USEPA (United States Environmental Protection Agency). 1992. National Water Quality Inventory, 1990. Report to Congress (EPA-503/99-92-006). Washington DC.

USEPA. 2000. National Water Quality Inventory, 1998. Report to Congress (EPA-841-R-00-001). Washington DC.

USEPA. 2007. Hypoxia in the Northern Gulf of Mexico: An update by the EPA Science Advisory Board, EPASAB-08-003. December 2007.

Woltemade, C.J. 2000. Ability of restored wetlands to reduce nitrogen and phosphorus concentrations in agricultural drainage water. Journal of Soil and Water Conservation 55(3):303-309.

Wossink, G.A.A., and D.L. Osmond. 2002. Farm economics to support the design of cost-effective Best Management Practice (BMP) programs to improve water quality: Nitrogen control in the Neuse River Basin, North Carolina. Journal of Soil and Water Conservation 57(4):213-220.
Xue, Y., M.B. David, L.E. Gentry, and D.A. Kovacic. 1998. Kinetics and modeling of dissolved phosphorus export from a tile-drained agricultural watershed. Journal of Environmental Quality 27:917-922.

Yates, A.G., R.C. Bailey, and J.A. Schwindt. 2006. No-till cultivation improves stream ecosystem quality. Journal of Soil and Water Conservation 61(1):14-19.

Zhu, Y., R.H. Fox, and J.D. Toth. 2003. Tillage effects on nitrate leaching measured by Pan and Wick lysimeters. Soil Science Society of America Journal 67:1517-1523. 